\title{
A Multiparadigmatic Approach to Judeo-Christian Religion in Social Work Education
}

\author{
Jon E. Singletary
}

\begin{abstract}
The attention given to faith-based human services in the past decade has created interest in pedagogical models of the ethical integration of spirituality, religion and social work practice. Following a discussion of philosophical, theoretical, and theological perspectives, this paper explores different sociological paradigms of knowledge and practice that may be of value when seeking to utilize spiritual and religious content into social work education. The implications of this article relate to educational settings that seek to incorporate content on religion and spirituality in social work education as well as to social work practice in religious organizations.
\end{abstract}

Keywords: Paradigm; religion; planning and administration

\section{INTRODUCING PARADIGMS}

The language of paradigms has been used across disciplines to describe current and shifting understandings of knowledges, beliefs, assumptions, and practices. Thomas Kuhn (1962) made the term "paradigm" recognizable with his publication of Structure of Scientific Revolutions. For Kuhn, a paradigm is a collection of shared beliefs, a set of agreements about how the world may be understood. According to Kuhn, the differences between Newton's mechanical universe and Einstein's relativistic universe represent a shift in paradigms. Each of these two approaches to physical science represent a worldview, or a paradigm, that guides how scientists see the world.

Hans Kung (1988) is among those who has applied Kuhn's understanding of paradigms to religion. He identifies several paradigms that have shaped religious history. Among recent Christian worldviews are the modern, Enlightenment paradigm and an emerging Ecumenical paradigm. In comparing these two paradigms, Frederick Schleiermacher's (1996; 2001) contributions that shaped much of modern liberal theology are challenged by the pluralism of more recent ecumenical and interfaith theological understandings (Cobb, 1982; Hick, 1982). The new does not replace the old, yet it does provide an alternative foundation of thought for understanding contemporary religious practices.

In Organization Practice: A Social Worker's Guide to Understanding Human Services, Netting and O'Connor (2003) bring the matter of paradigms to relevance in social work organizational settings. They define paradigm as a worldview containing deep-seated assumptions that are so much a part of a person that it is often difficult to step back and see what the assumptions are. Such assumptions and views of the world are central to a person's belief system and to the ways that a person lives and acts in relation to others. Netting and O'Connor encourage social workers to be able to practice multi-

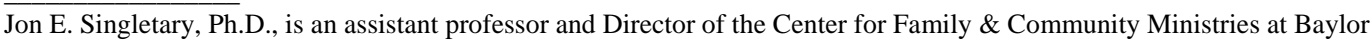
University.

Copyright (C) 2008 Advances in Social Work Vol. 9 No. 2 (Fall 2008), 63-78 
paradigmatically, to discern the assumptions most often used within an organization and then use critical thinking and practice skills to move across different paradigms to accomplish goals congruent with social work values.

This contribution by Netting and O'Connor builds on another text that focuses on paradigms and has relevance for practice and research in social work and religion: Burrell and Morgan's (1979) Sociological Paradigms and Organisational Analysis. Burrell and Morgan provide a discussion of four paradigms, as well as a philosophical understanding of each paradigm in terms of ontology, epistemology, human nature, and research methodology.

In the same way that Netting and O'Connor utilize Burrell and Morgan as a foundation for their work in social work organization practice, I build on both texts to propose multiple paradigms that can be utilized when including religion in discussions of social work, particularly in educational settings. This paper includes a discussion of philosophical assumptions, paradigms that emerge from these assumptions, examples of these paradigms in social work practice in religious organizations, and implications of these paradigms for social work education. The multiparadigmatic framework offered by Burrell and Morgan, as well as the adaptation for social work by Netting and O'Connor (2003; see also Martin \& O'Connor, 1989), will shape this effort to demonstrate the value of paradigms as heuristic tools for incorporating this approach to religious content in social work education and practice.

There are several practical and theoretical elements to think about when considering this multiparadigmatic framework for social work education. While the material may lead some readers to approach paradigmatic assumptions from a clinical perspective (Martin \& O’Connor, 1989), other readers may choose to approach this material from a generalist approach. With my interest and experience in planning and administration, I have found value in applying these paradigms with a focus on knowledge and skills relevant at the macro level of organization practice (Netting \& O’Connor, 2003; Netting, Thibault, \& Ellor, 1990). It is from this organizational perspective that I present the integration of religion in the paradigms and provide examples of religious organizations whose purpose and programs fits within the four paradigms.

To place the discussion of religion within the multiparadigmatic framework, a definition of religion may be of value. Religion and spirituality have a range of meanings in social work literature and are discussed in educational settings in a variety of ways (Bullis, 1996; Ellor, Netting, \& Thibault, 1999). For the purposes of this article, I understand religion to be a category for understanding the context of broad and diverse spiritual and sacerdotal practices engaged in by individuals and communities. I primarily discuss spirituality together with religion because so many spiritual practices traditionally developed within the context of a religion, yet because I also recognize that so many contemporary spiritualities are practiced outside the confines of a specific religion, I am attentive to the role of spirituality apart from religion (see Bullis, 1996). These understandings of religion and spirituality, in part, reflect paradigmatic differences. Issues related to defining religion and spirituality in social work education, as well as the 
issues related to the practices of religion, spirituality, and social work will be further discussed in terms of the framework of four paradigms to which I now turn.

\section{THE MULTIPARADIGMATIC FRAMEWORK OF BURRELL AND MORGAN}

Burrell and Morgan (1979) present a framework for understanding philosophical assumptions related to sociology and the place of organization theory in society. These foundations will be shown to be equally relevant to our discussions of faith, theology, religion, and spirituality. The core philosophical concepts they discuss are epistemology (the nature of knowing), ontology (the nature of what is known), and research methodology (processes for knowing).

\section{Philosophical Concepts of Knowledge}

Epistemology has to do with the nature of knowledge: how do we know what is true or real? Traditional sources of knowledge include intuition, perception, testimony, experience, and rational thought. Within religious history, there are four common sources: reason, revelation, tradition, and experience. There are, of course, variations on these sources and the weight they carry, with some sources dominating others. For example, the socially hegemonic force of authority seen in religious traditions tends to displace individual emotion as an experiential source of knowledge. Here, we begin to see one important factor: the distinction between hard knowledge, which is capable of being transmitted in a tangible form (e.g. the tradition of sacred writings), and soft knowledge, which is more innate and personal. These issues continue to be relevant to religious and secular debates about the grounds of knowledge as well as the ways knowledge is used.

Ontology addresses the nature of reality. Once we consider how we know, we then ask what we know. If we know about things divine through traditional sacred writings or through revelation, then what can be said about the nature of divine reality? Different sources suggest different ontological statements. Some traditional religious sources and many personal experiences allow people to present feminine characteristics of God; many sacred writings and other personal revelations describe masculine characteristics. Which is true? Which is real? You may say neither or both, but the issue is more than a matter of language. It is a matter of prayer, worship, service, and devotion and there are strong positions on either side arguing that gendered language for God does matter (Ruether, 1993). Another ontological theme relevant to religion is the discussion of whether our truths are external to the knower or the product of individual conscience; are they true or are they 'T'rue?

Methodology relates to practical matters of how we know and what we know. How do we investigate what is real? How do we receive truths? Consideration of subjective and objective ways of knowing points to both an epistemological question (e.g., what is the nature of how we know?) and a practical question (e.g., what are our processes for knowledge-building?). This and other relationships between these terms will be shown in the paradigmatic framework below. 
Burrell and Morgan (1979) arrange these concepts in terms of two dimensions that are presented as perpendicular linear continua. The result is a table of four paradigms (see Figure 1). In considering various philosophical issues of epistemology, ontology, human nature, and methodology, Burrell and Morgan identify schools of thought, such as social theories, within these paradigms and to this list, I place comparable theological perspectives. First let us consider the nature of the two continua and the four paradigms.

\section{FIGURE 1: $\quad$ Burrell and Morgan's Two Dimensions (1979, Figure 3.1, p. 22)}

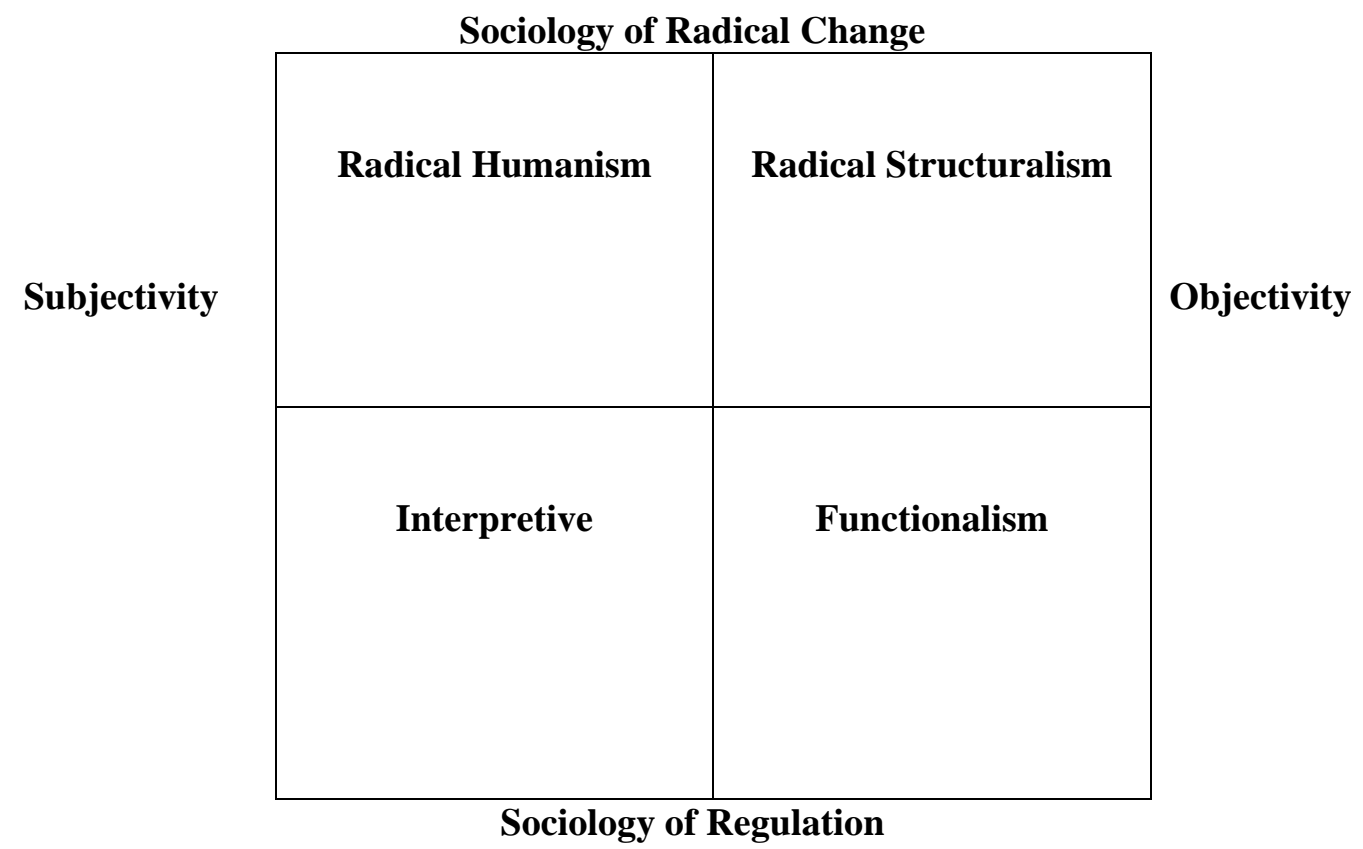

\section{Radical Change - Regulation}

Perspectives on the first continua, ranging from radical change to regulation, vary according to understandings of the inherent ordering or conflict present in a society. As you think about this continuum, there are a variety of issues to be considered: What role do both social work and religion have in a society? Are these disciplines more oriented to radical change or regulation? Should they be oriented otherwise? Each reader will approach these questions differently, and as a result, there are multiple perspectives that will be identified showing change oriented approaches to both social work (acknowledging the role of theories) and religion (acknowledging the role of theologies). Table 1 presents a variety of questions relevant to each side of this continuum. 
TABLE 1: The Continuum of Radical Change - Regulation

\begin{tabular}{ll}
\hline \multicolumn{1}{c}{ Radical Change } & \multicolumn{1}{c}{ Regulation } \\
\hline $\begin{array}{l}\text { Are our ways of knowing (epistemology) } \\
\text { focused on knowledge for action? }\end{array}$ & $\begin{array}{l}\text { Are our ways of knowing (epistemology) } \\
\text { focused on knowledge for knowledge } \\
\text { sake? }\end{array}$ \\
$\begin{array}{ll}\text { Are we focused on knowing in order to } \\
\text { bring about revolution? }\end{array}$ & $\begin{array}{l}\text { Is our focus maintaining traditions or } \\
\text { conserving norms? }\end{array}$ \\
$\begin{array}{ll}\text { Is our understanding of reality (ontology) } \\
\text { ever-changing? }\end{array}$ & $\begin{array}{l}\text { Is our understanding of reality (ontology) } \\
\text { relatively steady? }\end{array}$ \\
$\begin{array}{ll}\text { Are we free to understand differently or to } \\
\text { change society as new knowledges arise? }\end{array}$ & $\begin{array}{l}\text { Are we largely destined to know what we } \\
\text { know? To know within limits? }\end{array}$ \\
\hline
\end{tabular}

\section{Subjectivity - Objectivity}

The second continuum, ranging from subjectivity and objectivity, relates to assumptions about the nature of social science, the nature of knowledge about the world around us. From a subjective perspective, theories tend toward nominalism with an understanding that reality is a product of one's mind. This antipositivistic position regards knowledge as experienced and interpreted in a variety of ways according to different persons (consider constructivism or social constructionism). The objectivist perspective embraces realist and positivist views of the social world and of knowledge about the world. Objectivity assumes the existence of truth with a capital "T" that can be firmly known through a best way or a right way (positivism) or that can be approached or approximated with careful attention to our knowledge-building processes (postpositivism). Questions aligning us on this continuum are listed in Table 2 below.

\section{TABLE 2: The Continuum of Subjectivity - Objectivity}

\section{Subjectivity Objectivity}

Are there multiple ways of knowing? Is our Is knowledge best created by a scientific knowledge dependent upon and limited to our processes? method? Or, is knowledge granted to us by church tradition?

Are there multiple realities (subjectivity) Is there a single ultimate reality (objectivity)? 


\section{Four Paradigms}

From the matrix formed by the two continua, Burrell and Morgan offer their understanding of four paradigms that include: functionalism, interpretivism, radical structuralism, and radical humanism. Each paradigm contains separate explicit, mutually exclusive assumptions which take into consideration one's epistemology, ontology, human nature, and methodology as arranged on the two continua (See Figure 1).

The functionalist paradigm is found in the quadrant of objectivism and regulation. Many theologians, social workers, and other professionals, at least in terms of what "the powers that be" have to say about these disciplines, are situated in this paradigm. A rational, orderly approach to work and a feeling that there is "one best way" or a commonly accepted "right way" to accomplishing tasks characterize functionalism (Netting \& O’Connor, 2003). A postpositivist philosophy of science, central to social work research, depends on objectivity within standard quantitative methods. Similarly, most assumptions and theories that have guided social work practice in the twentieth century are also central to a functionalist paradigm (Burrell \& Morgan, 1979; Martin \& O’Connor, 1989; Netting \& O’Connor, 2003). In religion, theology is not dependent upon scientific epistemology, but the authority involved in much of Christian orthodoxy assumes that there is a large amount of objective Truth in its doctrine and practice making this paradigm seemingly appropriate to their beliefs about reality.

If the focus on objectivity is central to your understanding of social work and/or religion, but you are more oriented toward radical change, then the radical structuralist paradigm may be a better fit for you. There is found here a firm foundation for universal knowledge, as with functionalism, but there is more of a focus on large systems changes rather than incremental changes within the status quo. Jewish, Christian and other theologies of liberation (Ellis, 2004; Gutierrez, 1988), which seek to address social structures that are oppressive, and socially-engaged Evangelicalism (Sider, 1999), which is a more theologically conservative approach still addressing social power and privilege, offer appropriate, but substantially different models for this paradigm. Both make substantial theological claims of truth, yet realize that the practice (praxis) of this truth leads to social and economic change. Radical feminist theory (Calas \& Smircich, 1996) and theology (Heyward, 1984), calling for institutional transformation, and critical theory (Habermas, 1971; 1984), addressing conflict in societal power relations, are other perspectives that fall within the assumptions of a radical structuralist paradigm relevant to social work practice.

The interpretive paradigm has as its focus the consensus and equilibrium of the regulation perspective (qua functionalism), but is subjectivist in nature so that social reality is based on human experiences and exists primarily as human social construct (Burrell \& Morgan, 1979; Netting \& O’Connor, 2003). Similarly, interpretations of what is real reflect individual understandings and intersubjectively shared meanings. This paradigm may be a comfortable fit for Christian educators with knowledge of biblical hermeneutics, particularly Reader Response Criticism, and approaches shaped by Ricoeur (1976) and Gadamer (1989). Whether seeking to understand written texts or the lived

experiences of the populations served by social work, this paradigm assumes 
participation in a world of emerging, local truths. As such, constructive ethical relativism, influenced by situational ethics and cognizant of the importance of human relationships, can be valued in this paradigmatic perspective (Netting \& O’Connor, 2003; Rorty, 1999; Welch, 1989). Rather than seeing social issues in black and white, social workers who are comfortable with many shades of gray might see themselves in this paradigm.

The final of the four paradigms, where subjectivity meets radical change, is known as the radical humanist paradigm. With a focus on emancipating the human consciousness, a major concern of this paradigm is releasing human development from the constraints of the status quo (Netting \& O’Connor, 2003). Postmodern philosophers who concentrate on individual changes rather than social change, including Foucault (1980) and Derrida (1981) may be relevant to this paradigm. Due to their generalizing nature, few theoretical perspectives are found in this paradigm; rather, the individual focus of emerging spiritual, transpersonal and holistic practice modalities align with the assumptions of this paradigm (Netting \& O’Connor, 2003). Sufi Mysticism is one of the developments from a major religion, namely Islam, fitting within this paradigm. If you value the subjectivity of the interpretive paradigm, but feel that change emerging from understanding doesn't match your understanding of societal and individual conflict and even contradiction, then the change-oriented and consciousness-raising relativism of this paradigm may be a more appropriate fit.

\section{INTEGRATING RELIGION IN THE PARADIGMS}

Using this multiparadigmatic framework for understanding one's view of religion and of the world, social workers may be able to recognize and articulate more readily their own assumptions, beliefs, and values as well as those of coworkers, clients, and the organizations and systems where they find themselves. This framework serves as a heuristic that can be useful for persons learning about the meanings found in the intersections of religion and social work practice because it addresses philosophical theological assumptions that often remain tacit for both teachers and learners.

A brief analysis of religious organizations and some characteristics of their practice provide examples of social work practice in each paradigm. Religious organizations have a wide array of functions from sacerdotal responsibilities to addressing human needs. These organizations can be studied according to theological orientation, service delivery, organizational development and structure, administration, including the role of faith in the activities of these organizations (Cnaan, Wineburg, \& Boddie, 2000; Jeavons, 1998, 2001; Wineburg, 2001).

The following diagram (Figure 2 below) includes both practice theories and theological perspectives that may be of relevance to religious organizations or social workers with an interest in religion. Furthermore, it provides a way to visualize side by side the theory and theology (i.e., the knowledge, beliefs, and values) shaping intersections of religion and social work practice. Following this diagram, I present brief descriptions of real organizations that serve as exemplars meant to illustrate the practical side of the paradigmatic concepts. The names have been changed to protect the identity of the agencies, but their characteristics remain true to my experiences with an 
ethnographic study of each of them (Singletary, 2003). For each one, sources of knowledge and understanding are offered that may be explicit or implicit in the organization's practice. Also, individuals within the organizations approach practice and faith with different assumptions, but the principles guiding the organizations as a whole or their primary leaders are being considered.

\section{FIGURE 2: Theory, Theology, and Organization Practice Models in Four} Paradigms

\section{Radical Change}

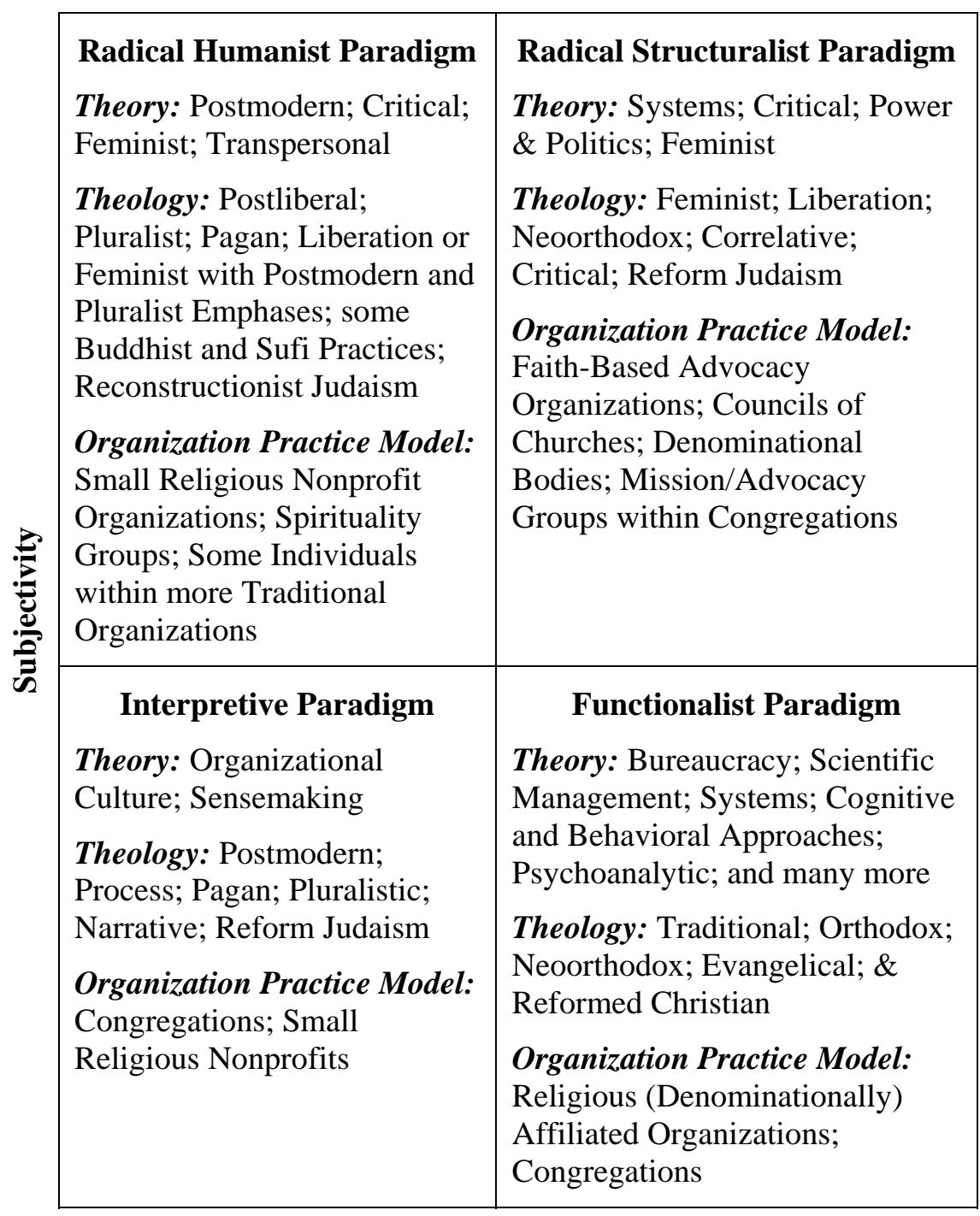

Regulation 


\section{Christian Ministries Incorporated: An Organization in the Functionalist Paradigm}

To begin with the functionalist paradigm, and an example relevant to current policy and practice, let us consider a Christian perspective that fits with an objectivist approach to knowledge (epistemology) and assumptions about Truth that is ultimately real (ontology). Many traditional views of God's revelation would provide an appropriate fit here. A functionalist approach to biblical texts may acknowledge subjectivity in reading, but assumes that ultimately objective Truth will be maintained by God's revelation through the Bible, religious tradition, and authority.

When seen from a modern mindset, we can identify Christian and Jewish organizations that align such a theology with their professional provision of social services. For example, there are Catholic, Mainline Protestant, and Jewish child welfare organizations that hold firmly to their doctrinal perspectives, and when it comes to providing social services, they hold equally tight to professional standards. As a part of this, they increasingly value evidence-based or theory-based practice. Religious affiliated agencies provide an example of this type of setting as they hope to achieve effective outcomes that demonstrate their understanding of an ethical realism stemming from God's love and justice, as well as, occasionally, from professional knowledge and values. Commonly, their perspectives are based on common assumptions that we are to serve and help meet the needs of others as the proper way of serving God.

Christian Ministries Incorporated, a large traditional religiously affiliated organization, exemplifies these functionalist assumptions. ${ }^{1}$ A statement of values posted near the entrance reads that the love and grace of God revealed in the person and work of Jesus Christ is to be demonstrated by staff and volunteers in all client interactions. A few lines below, the statement proposes that professional standards of confidentiality, respect, and dignity are also to be shown. According to the Executive Director, religious and social work values are well aligned in this organization that strives to incorporate theological perspectives reflective of their denominational teaching, as well as professional rigor in assuring measurable outcomes in their interventions. In this, Christian Ministries Incorporated affirms what has become commonly accepted in many social service organizations: the outcomes of human service programs can be evaluated by quantitative measures of effectiveness. True to a functionalist paradigm, these outcomes are said to be objective criteria for measuring the effectiveness of their theorybased interventions that also reflect "God's desire for social justice".

While working for change in their clients' lives, Christian Ministries Incorporated rests in the functionalist paradigm because the organization assumes commonly accepted expectations for service delivery. As a result, Christian Ministries Incorporated tends to promote change only in terms of what is expected and valued in their denomination's belief system and its acceptable standards that are reflected in this conservative Southern community. Due to funding constraints and a variety of philosophical and leadership considerations, they are not radically challenging the status quo- that is not the best use

\footnotetext{
${ }^{1}$ The examples all represent real faith-based organizations from practice experience, the names of which have been changed for this paper.
} 
of limited resources-yet they do meet a variety of real and growing needs in this community.

\section{Religious Women's Service Organization: A Radical Structuralist Organization}

In moving to the radical structuralist paradigm, where objectivity is valued as above, but where the goal of change is more radical, I present a recent program implemented in a feminist organization with a traditional religious name, but that has gone in very different directions from those originally conceived by the organization. Religious Women's Service Organization operates an advocacy program to change legislation that would protect women who have experienced domestic violence. The combination of feminist theory and liberation feminist theology allow the Center to some objective claims that are certainly of value; namely, that God has a preferential option for poor women and demands that we work to end the oppression and the experiences of abuse among low income women. These women work in protest against patriarchy and in solidarity with other women of various religions in the community.

Along with this position of objectivity in terms of what is true and right, one can see that they are also oriented toward radical change. On one hand, Religious Women's Service Organization offers shelter programs that promote change in the women's lives, but these commonly accepted programs fit into the status quo of what is acceptable for an organization such as this. On the other, more radical hand, the Religious Women's Service Organization is seeking to raise public awareness and advocating for legislative changes; in doing so, they are engaging in a marketing campaign that promotes change in public perceptions about women who experience abuse. They stand solidly in claiming the truth of their convictions and in calling others to join in their change activities.

This is an example of a radical structuralist organization because the assumptions are that the Religious Women's Service Organization has a perspectives about women's real needs and that their responses to the needs reflect God's teaching about what is ultimately best for these women (and, as a result, what is best for all of society). The Religious Women's Service Organization focuses their energy on changing other people's points of view to be more aligned with their own in an attempt to change social policies and promote social justice.

\section{Community Ministry Center: An Organization in the Interpretive Paradigm}

A new organization is being developed in our community that may be understood as interpretive. Let us consider this next as I move to a different set of assumptions about the nature of knowledge. Subjectivity and local meaning-making will be shown to be relevant in this paradigm.

The populations served, the programs that serve them, and the processes of the board structure at the Community Ministry Center are all emergent in nature as this young organization continues to create itself. While the Center does have a board and a director, the students and community members served by the Center take an active role in the consensus-building processes related to what the center does and what it will become. While developing out of a mainline Protestant Christian tradition, there is no commonly 
accepted theory base or single theological perspective driving the programs or servicesactually there may not be any programs or services offered in the traditional sense of the words!

The Center engages in a continual process of community praxis related at times to promoting social justice, but with an ever-present intentional focus on understanding the needs and desires of the multiple constituencies who occasionally gather at this space. This faith-based Center receives funding from its denominational body, but matters of meaning found in the faith are left to the discernment of individual participants in the community. Two groups met recently in this space--the leaders of one group were atheist and the other, Catholic--for a consensus building activity related to an upcoming community event. A similar example among leadership of the organization is seen as one month's board meeting began with a Bible reading and another with a Buddhist meditation.

The Community Ministry Center incorporates the consensus related perspective (of the regulation dimension) with subjective approaches to interpreting multiple realities (on the epistemological dimension) in ways that make a good fit in an interpretive paradigm. Participants in the diverse religious and spiritual views found in the broader community find a safe place to dialogue and reflect in this organization.

\section{All God's Children: Radical Humanist leadership in a Functionalist Organization}

Discerning a radical humanist approach to practice is not easy. The assumptions related to subjectivity and radical change relate more to individuals than organizations, particularly religious organizations. The closest organizational example is that of a small agency led by a woman trained in Cistercian, or "Trappist," monasticism yet who engages in the earth-based spirituality of deep ecology. The director of All God's Children, a local transitional shelter, works in a style befitting some of the criteria of radical humanism. To demonstrate this paradigm, I will discuss her style and a program they offer women leaving the agency.

Consistent with the radical humanist paradigm, All God's Children seeks change within individuals, but it seeks radical change from within the women rather than according to societal standards that are more in line with a functionalist paradigm. The director encourages the women individually and subjectively to discern what is best for them in the communities where they find support. It could be that living in community (similar to what the program offers) is what they feel is best for themselves, or that they take next steps to achieve independent living.

The termination program of All God's Children may be seen as a radical humanist service. She encourages the individual spiritual formation of the women through the practice of inner healing, a practice that encourages each woman to work toward her own transformation of mind, body, and spirit. The assumption is that spiritual formation leads to change and that it allows each woman her own subjective approach to meditative practice. These practices, allowing for individual change according to directions the women choose, provide some insight into radical humanist practice. The women feel a sense of power as they go, not "empowered" by the director but rather by their own 
process of spiritual direction. The approach is said to be a matter of consciousness-raising for the women with the potential for personal, social, and spiritual change.

\section{IMPLICATIONS FOR INTEGRATING MULTIPLE PARADIGMS}

A student beginning a placement in a religious organization recently realized that the questions she raised became more interesting (or confusing!) when she considered the assumptions that underlie the organization. While analyzing her organization in class, she identified the organization where she is placed as thoroughly functionalist because of programs offered and governance issues, yet states that the director is leading in an interpretive fashion that is more in line with her personality style. She observes the board president, who is expected to make a tough decision related to why things feel so dysfunctional and unproductive for everyone else, and a board vice president, who is content that everything will work out according to "God's plan". In this example and in many others, social work educators can formulate questions for students about guiding philosophical assumptions, sociological issues, approaches to knowledge, and overall views of the world. The multiple paradigms in this student's service system may have her bewildered about what direction the organization should go, but they offered a valuable framework for learning not only about her own perspectives but the perspectives of others.

One way to approach this example and others like it is to incorporate into classroom discussions some of the questions I raise above related to philosophical concepts of knowledge such as epistemology, ontology, and methodology. Specifically, before addressing social work theory, I ask students about paradigms using philosophical concepts and questions to guide the conversation. Subjectivity and objectivity are commonly discussed concepts in social work theory, practice and research, and as shown in Table 2, they represent philosophical issues. These philosophical issues undergird theological issues. Responses to these questions help students understand the differences between the four paradigms also discussed above. Conversations about religion are about values and beliefs, but the paradigmatic issues related to philosophy and theology underlying these values and beliefs contribute to deeper meaning when seeking to understand the role of religion in practice.

Learning about multiparadigmatic practice, as Netting and O’Connor (2003) describe it, goes well beyond simply identifying for ourselves, or our students, a paradigm of best fit. Realizing how we tire of being put in boxes, they suggest that this framework can be a guide for realizing that there is a range of alternative ways to know, experience, and engage the world (or worlds) around us. When we are able to recognize where we and others around us are "coming from," then we will be able to identify when our assumptions align with and when they conflict with others. We will be able to validate the existence of differences, and we hope that we will be able to put these differences to use as strengths (Netting \& O’Connor, 2003, p. 91-92).

To help students recognize personally how they understand and function in different paradigms, the questions presented in Tables 1 and 2 may be of value. From this conversation, we are able to shift the conversation to ask how these paradigms relate to 
religious perspectives. Figure 2 can be used in classroom discussions as a way to consider where students are most comfortable personally, but also to help them see where other individuals and organizations might be represented. Religious leaders in your community can serve as helpful resources for thinking about philosophical and theological themes that undergird practice. To interview religious leaders using some of the questions from this article may serve as a helpful way to teach this content.

Students may enjoy the process of finding the paradigm where they personally fit, but then struggle in realizing that their field placements, congregations, and universities may all be organized according to different assumptions and found in different paradigms. Students should not feel forced to merge the parts of themselves that are in one paradigm with parts of themselves in another, but to understand the differences that exist even within themselves. On one dimension, the goal may be to help them understand how they may have a subjectivist perspective that values multiple realities, yet participate in an organization that affirms objective Truth. On the other, they will occasionally be driven to radical change while in other situations and in response to other social or individual issues feel comfortable taking more incremental steps or maintaining accepted norms.

There will, of course, be other questions that can arise from paradigmatic considerations-questions that move from philosophical education to professional practice. Questions like these can be relevant not only to students, but to practitioners working with leaders of different religious backgrounds: How do we survive and thrive in organizations that promote incremental change supporting the status quo, when we value radical change? How do we design an intervention based on "one best way" when we feel that each individual must find her or his own way?

This paper introduces questions that are likely to develop when tacit assumptions become explicit in the self-awareness and critical thinking processes that are a part of social work education. These are not just philosophical issues, for they undergird a wide range of professional questions and concerns. Social work educators may consider not only how students respond to these issues, but also how practitioners utilize theology as well as theory in practice. For in the same way that we encourage critical thinking about theoretical perspectives in practice, we know that religious organizations, the people they employ and the people they serve, have beliefs and values that represent underlying theological perspectives.

The multiparadigmatic framework can raise questions about theological foundations; it can also help us address the ethical integration of faith and practice. Furthermore, this framework can provide guidance in shaping responses to philosophical and religious questions that arise in social work education and professional practice. Discovering the assumptions related to multiple paradigms of practice and theory may encourage students to articulate and ask questions such as those raised here. It may provide educators with the language and knowledge to respond with a heuristic model. And, it may contribute to the journey of lifelong learning for professionals seeking appropriate responses rooted in contexts of faith. Likewise, my hope is that the same implications can be found in practice settings. For organizations where religion is relevant, the themes addressed in 
this paper can help practitioners recognize the multiple ways in which religion and spirituality can be brought be bear upon organizational and community life.

\section{CONCLUSION}

The multiparadigmatic approach offered here reflects one understanding of the complex intersections of theory and theology and the integration of religion and social work practice. With the knowledge and expertise that social workers develop, as well as their own religious understandings, the information in this basic introduction to different paradigms of practice hopefully provides a heuristic for considering issues of religion from diverse perspectives. I feel that the information in this multiparadigmatic framework can be of value to social work students and practitioners, particularly social workers who work with people who are religious or spiritual, in organizations with a faith-based identity, or who are themselves religious or spiritual.

This understanding of paradigms may serve as a teaching tool for promoting increased self-understanding, for conducting organizational analysis, for evaluating practice theories, or for discussion related to the integration of religion and social work practice. The philosophical assumptions can be utilized in conversations about selfawareness and the professional use of self. The continua, as well as the paradigms, can also be of value in framing our use of practice theories and practice models.

This framework may also serve to aid in understanding differences and similarities among student assumptions about the world. Any time we say or hear, "Well, God expects us to...," "The Bible says...," or even, "the Code of Ethics demands..." we have an opportunity to reflect on our assumptions, and this matrix of paradigms provides a tool to aid us in considering these things. Whether used in teaching human behavior, practice or research, in discussing the relationships between faith and knowledge, or in introducing social work ethics in relation to different religious perspectives, this framework can be built into existing curricular materials in an effort to encourage students to consider the role of our many underlying assumptions that often go unnoticed and unmentioned.

\section{References}

Bullis, R. (1996). Spirituality in social work practice. Philadelphia: Taylor and Francis.

Burrell, G., \& Morgan, G. (1979). Sociological paradigms and organisational analysis Burlington, VT: Ashgate.

Calas, M. B., \& Smircich, L. (1996). From "the woman's" point of view: Feminist approaches to organization studies. In S. R. Clegg, C. Hardy, \& W. R. Nord, (Eds.), Handbook of organization studies (pp 218-256). Thousand Oaks, CA: Sage.

Cnaan, R. A., Wineburg, R. J., \& Boddie, S. C. (1999). The newer deal: Social work and religion in partnership. New York: Columbia University Press.

Cobb, J. B. (1982). Beyond dialogue: Toward a mutual transformation of Christianity and Buddhism. Philadelphia: Fortress. 
Derrida, J. (1981). Positions. Chicago: University of Chicago.

Ellis, M. (2004). Toward a Jewish theology of liberation. Waco, TX: Baylor University.

Ellor, J. W., Netting, F. E., Thibault, J. M. (1999). Understanding religious and spiritual aspects of human service practice. Columbia, SC: University of South Carolina Press.

Foucault, M. (1980). Power/knowledge. New York: Pantheon.

Gadamer, H. G. (1989). Truth and method. (Rev. ed., J. Weinsheimer \& D. G. Marshall, Trans.). New York: Crossroad.

Gutierrez, G. (1988). A theology of liberation: History, politics, and salvation $\left(2^{\text {nd }}\right.$ ed., C. Inda \& J. Eagleson, Trans.). Maryknoll, NY: Orbis.

Habermas, J. (1971). Theory and practice. (J. Viertel, Trans.). Boston: Beacon.

Habermas, J. (1984). Theory of communicative action: Reason and the rationalization of society Vol. 1. (T. McCarthy, Trans.). Boston: Beacon.

Heyward, C. (1984). Our passion for justice. New York: Pilgrim Press.

Hick, J. (1982). God has many names. Philadelphia: Westminster.

Jeavons, T. H. (1998). Identifying characteristics of “religious” organizations: An exploratory proposal. (Program on Nonprofit Organizations Working Paper \#197) New Haven, CT: Yale University.

Jeavons, T. (2001). Being faithful. Nonprofit Quarterly, 8(2), 37-39.

Kuhn, T. (1962). The structure of scientific revolutions. Chicago: University of Chicago Press.

Kung, H. (1988). Theology for the third millenium. New York: Doubleday.

Martin, P. Y., \& O’Connor, G. G. (1989). The social environment: Open systems applications. New York: Longman.

Netting, F. E., \& O’Connor, M. K. (2003). Organization practice: A social worker's guide to understanding human services. Boston: Allyn \& Bacon.

Netting, F. E., Thibault, J. M., \& Ellor, J. W. (1990). Integrating content on organized religion into macropractice courses. Journal of Social Work Education, 26(1) 15-24.

Ricoeur, P. (1976). Interpretation theory: Discourse and the interpretation of meaning. Fort Worth: Texas Christian University.

Ruether, R. R. (1983). Sexism and God-talk: Toward a feminist theology. Boston: Beacon.

Schleiermacher, F. (1996) On religion: Speeches to its cultured despisers Richard Crouter (Editor). Minneapolis: Fortress.

Schleiermacher, F. (2001). The Christian faith. (H. R. MacKintosh, Trans.). Minneapolis: Fortress. 
Sider, R. (1999). Good news and good works: A theology for the whole gospel. Grand Rapids, MI: Baker Book House.

Singletary, J. E. (2003). A constructivist inquiry of the meaning of church-state relationships for faith-based organizations. Unpublished Dissertation. Richmond: Virginia Commonwealth University.

Welch, S. D. (1989). A feminist ethic of risk. Minneapolis: Fortress.

Wineburg, R. (2001). A limited partnership: The politics of religion, welfare, and social service. New York: Columbia University Press.

\section{Author's note:}

Address correspondence to: Jon E. Singletary, Ph.D., School of Social Work, Baylor University, One Bear Place \#97320, Waco, TX 76798-7320. E-mail:

Jon_Singletary@baylor.edu. 